AperTO - Archivio Istituzionale Open Access dell'Università di Torino

\title{
Valuing externalities from energy infrastructures through stated preferences: A geographically stratified sampling approach
}

\section{This is the author's manuscript}

Original Citation:

\section{Availability:}

This version is available http://hdl.handle.net/2318/1559840

since 2016-11-30T17:11:38Z

Published version:

DOI:10.1080/00036846.2016.1178850

Terms of use:

Open Access

Anyone can freely access the full text of works made available as "Open Access". Works made available under a Creative Commons license can be used according to the terms and conditions of said license. Use of all other works requires consent of the right holder (author or publisher) if not exempted from copyright protection by the applicable law. 

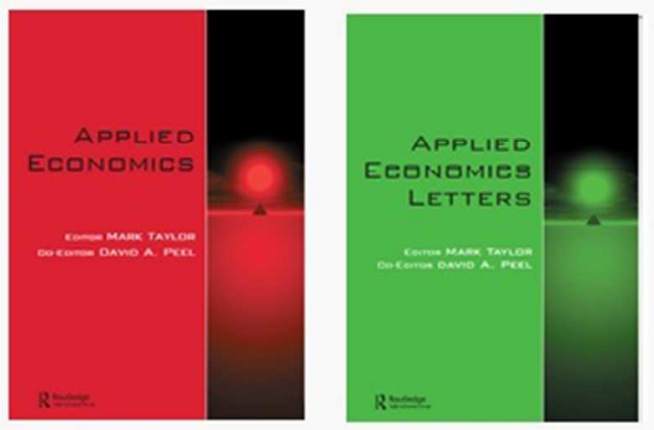

\section{Valuing externalities from energy infrastructures through stated preferences: A geographically stratified sampling approach}

\begin{tabular}{|c|c|}
\hline Journal: & Applied Economics \\
\hline Manuscript ID & APE-2016-0010.R1 \\
\hline Journal Selection: & Applied Economics incorporating Applied Financial Economics \\
\hline Date Submitted by the Author: & $\mathrm{n} / \mathrm{a}$ \\
\hline Complete List of Authors: & $\begin{array}{l}\text { Giaccaria, Sergio; Joint Research Centre Institute for Energy and } \\
\text { Transport, Energy Security, Systems and Market } \\
\text { Frontuto, Vito; University of Turin, Department of Economics and Statistics } \\
\text { Dalmazzone, Silvana; University of Turin, Department of Economics and } \\
\text { Statistics }\end{array}$ \\
\hline JEL Code: & $\begin{array}{l}\text { C21 - Cross-Sectional Models|Spatial Models < C2 - Econometric Methods: } \\
\text { Single Equation Models < C - Mathematical and Quantitative Methods, D62 } \\
\text { - Externalities < D6 - Welfare Economics < D - Microeconomics, H50 - } \\
\text { General < H5 - National Government Expenditures and Related Policies < H } \\
\text { - Public Economics, O13 - Agriculture; Natural Resources; Energy; } \\
\text { Environment; Primary Products < O1 - Economic Development < O - } \\
\text { Economic Development, Technological Change, and Growth, O22 - Project } \\
\text { Analysis < O2 - Development Planning and Policy < O - Economic } \\
\text { Development, Technological Change, and Growth }\end{array}$ \\
\hline Keywords: & $\begin{array}{l}\text { High Voltage Transmission Lines, externalities, contingent valuation, stated } \\
\text { preferences, GIS }\end{array}$ \\
\hline
\end{tabular}




\author{
Sergio Giaccaria ${ }^{\mathrm{a}}$, Vito Frontuto ${ }^{\mathrm{b}}$, Silvana Dalmazzone ${ }^{\mathrm{b}}$ \\ a Joint Research Centre of the European Commission, Institute for Energy and Transport, \\ Petten (The Netherlands) \\ b Department of Economics and Statistics, University of Turin (Italy). \\ Lungo Dora Siena , 100/A, I-10153 Torino - Italy \\ Corresponding author: Sergio.GIACCARIA@ec.europa.eu
}

\begin{abstract}
The externalities produced by high voltage transmission lines are multi-dimensional, may strongly depend on the local context, and are thus difficult to capture through standard environmental valuation exercises. We experiment a GIS approach to design a geographically stratified contingent valuation sample of the population resident in infrastructure corridors in a whole region. We estimate, by means of a binary choice logit model, the perceived marginal damage from impacts of power lines on human health, the landscape and the environment. Specific treatment is given to qualitatively different forms of impact, namely real estate depreciation $v$ s. diffused perception of damage, arising at different distances from the lines. The set of GIS-based variables (proximity to power lines, presence of other infrastructure, endowment of natural and built heritage and other local context variables) prove to be significant predictors in the utility function of resident households. Finally, we compute simulated values that combine information on individual willingness to pay, population density and the dimension of the considered corridor around the infrastructure, so as to generalize the outcomes of case-specific studies for use in policy choices such as infrastructure localization, undergrounding and negotiation of compensations.
\end{abstract}

Keywords: High Voltage Transmission Lines, linear infrastructures, externalities, contingent valuation, stated preferences, GIS.

JEL Classification: $C 21, D 62, H 5,013, O 22, Q 4$.

Acknowledgements. This paper draws from results of a research project funded by the Directorate of Environment of the Piedmont Region and the Office for the Evaluation of Public Investments of the Piedmont Region (NUVAL). We are grateful to Ugo Colombino, Edward Morey, Anna Alberini and Riccardo Scarpa for suggestions on the design of the experiment and methodological insights. 


\section{Introduction}

Being able to estimate the unpriced impacts caused by the generation and transport of energy is increasingly recognized as a key factor in the design of efficient energy policies, both in public and in private energy industries (Pearce, 2001). Internalizing health, environmental and landscape externalities is the basic criterion (typically inspired by a welfare economics perspective) driving the rationalization of decision processes in the evaluation of investments in the energy sector. The availability of information, in the form of monetary estimates of different typologies of externalities, is the binding constraint in making this economic approach operational. Results of ad hoc monetary valuations, usually focussing on one or a few of the many dimensions of damage and set within one specific geographical context (urban, rural, touristic and so on), are seldom suitable for benefit transfer and generalizations. Thus, despite the appreciable number of empirical studies on the economic cost of infrastructure externalities and their collation by independent research programmes (European Commission, 1995; CSERGE et al., 1999), the valuation of external costs of electricity transport facilities does not yet provide satisfactory insight to policy makers.

A large share of previous studies was conducted in North America by means of the hedonic pricing method (Kinnard, 1967; Colwell and Foley, 1979; Colwell, 1990; Kroll and Priestley, 1992; Kung and Seagle, 1992; Delaney and Timmons, 1992 for the United States; Des Rosiers, 2002 in Canada). McNair and Abelson (2010) estimate by hedonic pricing the value of undergrounding electricity and telecommunication networks in Australia. A contingent valuation (CV) study by McNair et al. (2011a,b) estimates the willingness to pay for undergrounding portions of the distribution (Low Voltage) network, again in Australia; a recent work by Ju and Yoo (2014) measures the environmental costs of overhead power transmission lines in Korea by using a choice experiment (CE).

In the European context, three hedonic pricing studies have been conducted in the UK (Gallimore and Jayne, 1999; Sims and Dent, 2005, May et al. 2011). Stated preferences analyses are due to Atkinson et al. (2004) who, by means of a choice modelling experiment, obtain (negative) willingness to pay estimates for different types of transmission towers in the UK; in Italy, Rosato et al. (2004) who use CV to estimate the visual and health benefits of undergrounding transmission lines in proximity to urban centres, and Tempesta and Marazzi (2005) who again through CV estimate the damage to the aesthetic quality of landscapes; and Navrud et al. (2008) who, once more through contingent valuation, estimate households willingness to pay for reducing landscape disamenities caused by transmission lines in Oslo. ${ }^{1}$

This paper, building upon previous literature, aims to provide a first large-scale study of the externalities caused by high voltage transmission lines (HVTLs) in a European region. Likewise most recent studies, it uses contingent valuation: stated preferences are often given preference in evaluating the externalities from energy infrastructures as they allow us to obtain estimates closer to the total economic value, including depreciations suffered by home owners but also perceived environmental impact and all those diffuse effects that

${ }^{1}$ Further studies investigate public perception of externalities caused by electricity transport or generation facilities by means of non-monetary techniques. Soini et al. (2011), for instance, analyse the heterogeneity of the perceptions of transmission lines in Finland by using a latent class model. Cotton and Devine-Wright (2013), using deliberative focus group methods, explore perceptions of environmental and social impacts of high voltage transmission lines in the UK. Medrano and Church (2014) use a single-objective shortest path algorithm to support corridor location choices for linear infrastructures, including transmission lines. Ek (2005) explores the attitudes towards wind power among the electricity consumers through a postal survey on Swedish house owners. Sumper et al. (2010) develop a participatory methodology to evaluate the multi-dimensional impacts of high voltage lines in urban areas. 
would hardly be reflected in the real estate market. In addition, hedonic pricing requires data on property values that, in Italy as in many other countries, can only be obtained by observing real estate transactions - a small subset of the actual universe.

The study is set in the largest northern Italian region. The wide coverage (in terms of both population and land surface), including urban, rural and mountain areas, marginal and degrades sites as well as areas of landscape and touristic interest, enhances comparability and replicability in different contexts.

The purpose is not only to provide monetary estimates of the external costs involved in one specific case but also to offer decision-makers an implementable decision support tool. Even though the transfer of willingness to pay values in different contexts (particularly where socio-economic variables vary markedly) should always be handled with care, the scale and geographical stratification of our approach helps improving our understanding of the general determinants of infrastructure externalities. Potential applications include the location choices and the calculation of reference values for the arrangement and negotiation of compensative measures at the local level. ${ }^{2}$

Our CV is aimed at estimating households' measures of willingness to pay (WTP) for an environmental change concerning a hypothetical scenario of removal of the power lines contiguous to the respondent dwelling. The elicitation is based on the binary single bounded dichotomous choice format, proposed by Hanemann (1984) and recommended by the National Oceanic and Atmospheric Administration (NOAA) panel for its incentive compatibility (Arrow et al., 1993). ${ }^{3}$ It allows us to define a relationship between WTP and other observable explanatory variables affecting the deterministic component of the respondents' utility function.

The reference population is the households residing in the corridors around HVTLs, as defined in Section 2. Because the hypothetical scenario matches the actual residential location of respondents, our analysis can include further information about the spatial and environmental structure of the interaction between households and power lines, thus taking up Bateman's (2002) argument in favour of giving more attention to the spatial structure of environmental phenomena on the part of econometric models employed in environmental and natural resource economics.

We suggest that in the case of linear infrastructures the way individuals perceive the externalities depends on the local context - for example whether the area is of high naturalistic or landscape value, or rather already environmentally degraded by the presence of other infrastructures and disamenities. To account for context-dependence in a similar perspective Anselin (2003) proposes the concept of "spatial externality". Spatial patterns have already been pointed out as relevant explanatory contextual factors in rural land use choice (Bockstael, 1996) and in the valuation of rural amenities (Johnston et al., 2002).

The link between preferences and other micro-spatial characteristics is built making use of the geographical information system (GIS) to map and collect quantitative variables that are then tested as explanatory variables of the WTPs. We use well-experimented distancebased approaches (Bateman, 2002) to include among the explanatory variables the proximity of respondents to the infrastructure being valued and other features pertaining to the local context (density of the local power line network, presence of other infrastructures such as railways or highways, highly polluted and contaminated sites, presence of protected areas and other environmental ties as a proxy of environmental quality, natural and historical heritage).

\footnotetext{
2 The results of our research can also serve as an informational basis for the implementation of software based tools, such as EcoSense (Krewitt et al., 1995), designed for ex-ante simulations and scenario analysis.

${ }^{3}$ The NOAA Panel is a distinguished team of social scientists, chaired by two Nobel laureates, Kenneth Arrow and Robert Solow, appointed in 1992 by the US Administration to critically evaluate the validity of $\mathrm{CV}$ measures of non-use values of environmental resources.
} 
One of the paper's objectives is to verify whether the perceived externalities are sensitive to these micro-spatial features, which we call local context variables (LCVs).

The paper is organized as follows. In Section 2 we illustrate the structure of the case study; in Section 3 we present the econometric models, and Section 4 reports the results of the estimated models. Section 5 concludes.

\section{Experiment design}

Our study area is the Piedmont Region in the north-western part of Italy. The experiment involved a large sample of households living in proximity of the actual HVTLs of the entire regional network (described in \$2.1). As a consequence of the experimental design, the households interviewed were well-informed and familiar with the infrastructure. The exclusion of non-resident and tourist preferences from the sample is due to our intention to obtain estimates useful also as reference points in the arrangement of compensative policies.

The target of the contingent valuation consists of the bundle of environmental, human health and landscape externalities produced by HVTLs. The spatial context in which the externalities of linear infrastructures are perceived is conventionally identified by means of corridors. Socioeconomic and ecosystemic impacts on ecosystems are more intense in these areas (Geneletti, 2002). The choice of the corridor width plays an important role in the experiment design. A review of the existing empirical studies, summarized in Table 1, shows widths of the HVTL corridor varying between 122 meters and 5 kilometres. A corridor, however, includes sub-areas among which the impacts of power lines vary depending on the shape and size of the towers, the orographic trim, climatic conditions and the presence of vegetation. In view of the high variability of the territory crossed by HVTLs in our case, we consider a corridor of 1200 meters. The maximum distance between interviewed households and power lines is hence 600 meters. $^{4}$

\section{Table 1. Existing monetary valuations of HVTL externalities}

(Approximately here)

We overlaid the 1200 meter corridors around the HVTLs on the official regional cartography ${ }^{5}$ and on existing geographical analyses of the Piedmont region providing a zoning in sub-regional macro-areas (Clementi, 1996). These macro-areas are sample strata (Figure 1) that have an appreciable degree of internal homogeneity from the point of view of settlement and landscape typologies, vegetation and orography.

Figure 1. Map of sample strata

(Approximately bere)

Considering the lines with a tension of $132 \mathrm{kV}, 220 \mathrm{kV}$ and $380 \mathrm{kV}$, the regional HVTL network crosses 786 municipalities and involves a target population of 2,613,904 inhabitants

4 Rosato et al. (2004), in their CV study on HVTLs, define a corridor of 1200 meters as "the corridor interested by direct impacts of visual encumbrance and health risk" (our translation).

5 The set of Technical Regional maps, at a scale 1:10000. 
living within the infrastructure corridors. The number of interviews was divided among the macro-areas on the basis of the size of the resident population in the HVTL corridor. The total number of interviews for macro-area was then allocated among municipalities, using a density index of power lines. ${ }^{6}$

\subsection{The survey dataset}

Using GIS, we identified approximately 5,000 households living within the corridors and we contacted them by letter informing them that they had been selected as potential participants in a survey promoted by the Piedmont Region and the University of Turin. We subsequently interviewed 2,000 individuals, randomly selected, by telephone. People stating a zero WTP were asked to explain the reason: through their answers we distinguished and excluded protest responses (more likely associated with the denial of the valuation scenario or with a protest strategic behaviour) from the 'true' zeros (Mitchell and Carson, 1989; Strazzera et al., 2003). After removing protest responses and incomplete interviews, our final dataset consists of 1,410 valid observations, with a response rate of $70 \%$.

Table 2 reports descriptive statistics for the respondents' characteristics. The average age of respondents is 52 years (against a national average of 45.19). Women represent $64 \%$ of the sample (national average 51.76). The mean of years of schooling is 9.87 (national average $9.38^{7}$ ) and $46.7 \%$ of the respondents have a high school or more advanced degree (national average $40.24 \%$ ). Families are on average composed by 2.9 people (national average 2.2 ) and children are present in $28.5 \%$ of them. The average stated household income is $€ 22,800$ per year, in line with the national average. The fact that most of the HVTL network corridors run across rural rather than urban areas (where they are mostly underground) explains the differences between average age and family size in our sample and the national average values. The gender unbalance of respondents, instead, is likely due to the lower female employment rate in rural areas with respect to the national average (Ecorys, 2010), which increases the share of women respondents to the random telephone interviews. We decided to retain the original sample, without weighting procedures, after checking that the gender effect on the WTP turns out to be negligible, as discussed in section 4.

Table 2. Descriptive statistics (Approximately bere)

The local context variables provide us with information on the spatial context the respondents live in: their houses are on average at a distance of 324 meters from the power lines, and $3 \mathrm{~km}$ and $2.1 \mathrm{~km}$ from rails and highways, respectively. The average percentage of area covered by the HVTL corridors in different municipalities is $39.2 \%$, and in $72 \%$ of the cities in which the interviews were collected there is at least one area protected by law for its environmental or cultural relevance.

\subsection{The CV scenario}

The contingent valuation approach, as other stated-preference valuation methods, employs simulated scenarios to estimate the welfare impacts of environmental changes. In the

6 The density index of power lines was defined as the dimensionless ratio between the corridor area and the municipal area.

${ }^{7}$ Last Italian population survey (ISTAT, 2013). 
dichotomous choice format, the elicitation of WTPs is based on the (stated) acceptance or rejection of a bid to access this hypothetical scenario. The scenario proposed in our survey uses a referendum format: it envisages a regional program for the modernization and rationalization of the power line network, involving the removal or undergrounding of some portions of the infrastructure. Carrying out this program requires a contribution by citizens.

If the choice of the payment method is an important element in CV experiment design, the time path of these payments may also play an important role. Previous studies on the socalled intertemporal bias show that the present value of the WTP elicited when the payment is distributed over a longer time horizon is consistently higher than that elicited when the payment is on a shorter time horizon or a lump-sum amount (e.g. Bateman and Langford, 1997; Stevens et al., 1997; Stumborg et al., 2001; Chen et al., 2014). Payments under the form of annual amounts thus tend to overstate the present value of the WTP. This may be partly related to private discount rates empirically proving to be much higher than market rates, and partly to difficulties by individuals in accurately taking into account their rate of time preference (Whitehead and Blomquist, 2009). In order to mitigate temporal bias we therefore opted for presenting the payment in the form of a lump-sum tax, and considering the potential underestimate of true WTP in discussing the results.

The hypothetical market thus takes the form of a local political market:

"...Suppose that your municipality, in order to decide whether to demolish a $5 \mathrm{Km}$ portion of HVTL, is asking the opinion of citizens through a referendum. If you vote NO, the portion of power line will not be removed. If you vote $\mathrm{YES}$, the line will be removed, but all of the citizens will have to contribute the payment of a lump-sum tax. If the amount of the tax were X Euro, would you vote Yes or No?"

The length of the portion to be removed, $5 \mathrm{~km}$, reflects the scale of the decision (set at the municipal level) and corresponds to the mean value of the length of HVTLs crossing municipalities in the observed region. The scenario appears to be credible because in the same period the Piedmont Region implemented a policy to underground some portions of HVTLs.

Households were asked to reveal the damage they perceive due to the HVTL in their own specific context: the valuation is not referred to an abstract and standardized scenario but to the real environment in which the respondent-infrastructure interaction takes place. Because respondents were well-endowed with first-hand information on the scenario, the implementation of visual and other informative supports during the interview was assumed to be useless, if not counterproductive. ${ }^{8}$

The estimated willingness to pay aims at reflecting the perceived value of the overall impact deriving from all relevant externalities connected with the presence of HVTLs. To this purpose, a section of the questionnaire is dedicated to acquiring an individual description of the components of damage (e.g., perception of risk for human health, visual encumbrance, other external effects for landowners) and their ranking.

\subsection{Pre-test}

The bid vectors were defined through a process involving an exploratory pre-test. Open-ended elicitation questions were employed in the pre-test on a sample of 100 respondents, to obtain preliminary indications on the maximum WTP values. Most respondents living in close proximity to the lines, within 50 meters, indicated WTP values between $€ 10,000$ and $€ 20,000$, explained by the negative impacts of the infrastructure on real estate property

${ }^{8}$ In the contingent valuation literature there is evidence that the effect of providing informational support on WTP values depends on the level of prior information (Tkac, 1998), improving the study design only if the information given is truly new for the respondent (Hoehn and Randall, 2002) and the level of involvement in the good being evaluated is low (Ajzen et al., 1996). 
Figure 2. Price vectors auto-selection criterion (Approximately here)

Although the choice of the bid vector values represents a potential source of anchoring bias for WTP estimates, results of the pre-test suggest that the overall population may have a clustered structure. Therefore we test in a pooled analysis, as explained in the next section, whether preferences of the three groups follow a common preference structure or they differ substantially.

\section{Econometric strategy}

Given the single-attribute nature of our scenario, for the elicitation of WTP we consider a single bounded binary choice, in compliance with the recommendations of the NOAA panel for incentive compatibility (Arrow et al., 1993). ${ }^{9}$ This format draws on the seminal work by Bishop and Heberlein (1979), extended by Hanemann (1984), who proposed the single bounded model as theoretically consistent with the random utility framework.

The indirect utility $V(y, q)$ is defined as the maximum utility attainable by the interviewed households given income $m$ and environmental quality $q$. The WTP to obtain quality $q_{1}$ when facing quality $q_{0}$ is implicitly defined by the condition

$$
V\left(y-W T P, q_{1}\right)=V\left(y, q_{0}\right) .
$$

WTP, in this framework, measures the compensative surplus - the amount of income that the respondents would be willing to pay in order to obtain the environmental change proposed by the hypothetical scenario, keeping their initial level of welfare unchanged.

\footnotetext{
9 Many other monetary valuations of energy policies that need to assess multiple project options or scenarios within a single survey make use instead of choice experiments (e.g. Borchers et al., 2007; Scarpa and Willis, 2010; Longo et al., 2012; Sardianou and Genoudi, 2013) and CVs with sequential dichotomous choice questions (Longo et al., 2015). Telser and Zweifel (2007), Giaccaria and Frontuto (2012) and Xie et al. (2014) are examples of Discrete Choice Experiments, CE and BestWorst Scaling respectively for the valuation of multiple scenarios of health risk.
} 
If the individual is asked to pay a sum (a bid) $B$ in order to replace $q_{0}$ with $q_{1}$, he or she will accept the bid if $B \leq W T P$.

The WTP is specified as:

$$
W T P=\beta^{\prime} z+\varepsilon
$$

where $z$ is a vector of variables measuring individual and environmental characteristics, $\beta$ is a vector of parameters to be estimated via maximum likelihood and $\mathcal{E}$ is a random variable with zero mean and variance $\sigma^{2}$, accounting for unobserved variables.

The probability that a bid $B$ is accepted is therefore

$$
\operatorname{Prob}(W T P \geq B)=1-F\left(\frac{\beta^{\prime} z-B}{\sigma}\right)
$$

To test whether the three typologies (or intensities) of damage of the three bid vectors are correctly representing different coexisting relationships between preferences and WTP or whether they belong to the same shared preference structure, we use a pooled model. The bid terms are implemented in interaction with three dummies (one for each bid vector) with the following specification of the indirect utility function:

$$
v=\gamma_{1} \cdot b i d+\gamma_{2} \cdot d_{2}+\gamma_{3} \cdot d_{3}+\boldsymbol{\beta} S
$$

where $d_{2}$ and $d_{3}$ are two dummy variables identifying cases belonging to bid vectors 2 and 3 , and $\boldsymbol{\beta} S$ is a vector of socio-demographic variables. If $\gamma_{2}=0$ and $\gamma_{3}=0$ the model collapses in a simple unified structure: respondents evaluate the same underlying welfare effect even if they describe different typologies of perceived damage. If the null of $\gamma_{2}=0$ and $\gamma_{3}=0$ can be rejected, then respondents manifest a true distinction among types of damage, with a distinct preference structure associated with each bid vector. From a behavioural point of view, in the latter case we suggest that respondents that own a house in extreme proximity to the lines do not only consider potential impacts on health or landscape: their WTP is also determined by their perception of the impact of HVTL on the value of their property on the real estate market, which changes the order of magnitude of their WTP.

The set of explanatory variables $\boldsymbol{\beta} S$ includes:

- income (household's net income)

- education (total number of years)

- presence of children (younger than 14) in the household

- type of impact ranked by respondents as the most relevant among landscape, health, and ecological/biodiversity impacts.

The use of the GIS procedures of buffering and distance analysis allows us to include further information on the valuation context. This subset of LCVs includes:

- the distance between the nearest power line, source of the externalities, and the house of the respondent;

- highways, railways, contaminated or highly polluted sites (each of them modelled in terms of presence within a threshold distance);

- the presence of protected areas or other environmental ties giving a special status to sites with habitat rarity or specific value; 
- the aesthetic quality of the landscape, due to both natural and built components: a specific census of the historical built heritage and rural landscape amenities (SITA) allows us to include the total number of these local public goods in the municipality where respondents live.

\section{Results}

The results of the pooled analysis are reported in Table 3. The full model (model 1) is a baseline specification that implements the complete set of regressors: the bid, two interaction terms capturing the potential structural difference among bid vectors, the set of sociodemographic and perception variables, and the LCVs. We use this specification to test: (i) the differentiation of the preference structure across bid vectors, with a null hypothesis of equivalence of all of the bid and interaction terms, and (ii) the explanatory power of LCVs, in terms of improvement of the model's global goodness of fit.

A first set of Likelihood Ratio (LR) tests on model 1 allows us to reject both the hypothesis $\gamma_{1}=\gamma_{3}$ and $\gamma_{2}=\gamma_{3}$, confirming at a $95 \%$ level of confidence that the heavy damage subsample (bid vector 3 ) does not share the same preference structure of the overall sample. We cannot reject the hypothesis of equivalence between $\gamma_{1}$ and $\gamma_{2}$, a result suggesting that vector 1 and vector 2 can be assumed to have the same latent WTP distribution, with differences in terms of intensity of the perceived damage from the HVTL. ${ }^{10}$ The structural difference between the first two subsamples and the one of bid vector 3 suggests that the latter group structures the assessment process according to a different behavioural pattern. Our interpretation, as anticipated above, is that respondents associated with vector 3 (which includes only residents who own their house) calculate their WTP based on their perception of the depreciation of their property due to the HVTLs that is, based on their presumptions about housing market preferences. Their evaluation of the change in utility depends, in other words, on their expectations about others' preferences and takes the form of a capital gain associated with the removal of the power lines. The scale of this type of gain leads to "overwriting" the benefits associated with the elimination of environmental and health impacts.

The explanatory power of the LCVs is confirmed; the equivalence between model 1 and model 2 is rejected by LR test at a $99 \%$ confidence level.

Unconditional WTPs are provided in Table 4, which reports within a simple constant bid logit model the mean/median and the estimates of confidence intervals for the three groups of respondents. More detailed estimates for specific individual and location characteristics are supplied by the conditional values obtained from the pooled analysis (Table 3). The interval of the WTPs is $€ 178-200$ in the case of the vector 1 subsample, $€ 512$ 626 for the vector 2 subsample and $€ 2,758-4,748$ for the vector 3 subsample. This first result should be considered as the monetary evaluation of the perceived damage for each subsample.

Table 3. Full and reduced models for pooled analysis

(Approximately bere)

${ }^{10}$ The unconditional estimates are reported in Table 4, with the results of the split analysis. 
Table 4. Estimation on subsamples. Unconditional WTP and confidence intervals (Approximately bere)

The perception variables identify the type of impact considered as most prevalent by the respondent when given the choice between visual, ecological and health impacts. Their insertion in the model allows us to investigate the relative weight of the different motives of public aversion to power lines. The component of damage about which respondents turn out to be most concerned is 'human health risks' (52.6\%). For $22.3 \%$ of the respondents the visual impact on landscape quality is the most relevant, while only $6 \%$ consider environmental impact as the most serious form of damage. $17 \%$ of the sample reported they do not suffer any damage from the infrastructure.

The three dummy variables identifying the perception, socio-demographic and local context variables are highly significant. Omitting the constant term, in model 1 we consider three separate impacts associated with distinct components of utility: calculated marginal WTP amount to $€ 160$ for health impact, €147 for ecological/biodiversity impact, and approximately $€ 121$ for visual encumbrance.

Among socio-demographic variables, the income level is, as expected, statistically significant and with a positive coefficient. A high level of education also has a positive and statistically significant coefficient: respondents with a higher education degree are willing to pay, ceteris paribus, €108 more. Furthermore, the presence of children in the family implies higher WTP, presumably due to a desire to protect them from potential health risks. Parents are willing to pay more (around $€ 60$ more) than their childless counterparts, a result in accordance with both the economic literature concerning the valuation of environmental improvements (Dupont, 2004) and studies on environmental attitudes in sociology and psychology (Bord and O'Connor, 1997; Stern et al., 1993). The gender effect, although statistically significant, is economically negligible, with a coefficient two orders of magnitude smaller than that of all other dummies (presence of children, transport infrastructures, contaminated sites, protected areas): female respondents are willing to pay, ceteris paribus, $€ 0.57$ more than male respondents.

\subsection{The distance effect}

The issue of the proximity of the infrastructure has relevant implications. From an operational point of view, the possibility of estimating WTPs conditional on distance offers valuable informational support for the design of compensation policies.

The proximity to HVTLs is implemented in our model in the form of Euclidean distance. Alternative spatial weighting approaches exist. ${ }^{11}$ It is beyond the scope of this paper to build a comparative analysis of the many available weighting strategies (resistance functions, kernels, logarithmic or other distance transformations). Indeed distances, as well as other LCVs, are still generally modelled in the absence of a consolidated and standardized methodology for their coding. In the words of Bavaud (1998: p. 1):

'[...] for there is no such thing as "true", "universal" spatial weights, optimal in all situations: good candidates must reflect the properties of the particular phenomenon, properties which are bound to differ from field to field. On the other hand, this difficulty should not impede a more systematic investigation of models for spatial weights, starting with the question 'which classes of models yield specified families of spatial weights, and what are the properties of the latter?"

${ }^{11}$ We use spatial weights in order to code single characteristics of the household locations, rather than to deal with spatial autocorrelation or spatial dependence as in the case of SAR or spatial lag models (Anselin, 1988). 
Our analysis also contributes to the as yet inconclusive evidence on the shape of the relationship between perceived damage and distance from the infrastructure emerging from the literature. Kroll and Priestley (1992) in their survey assert that on average the existing valuation studies do not find a significant decrease in property values linked to the presence of HTVLs. In a few CV studies (e.g. Rosato et al., 2004) the distance from power lines does not appear to influence the willingness to pay. Other studies find instead a linkage between intensity of the damage and distance from the lines: according to Colwell and Foley (1979), for instance, there is a depreciation effect for houses within 60 meters of the power line, which is particularly significant for those situated within 15 meters. A group of applications of the hedonic pricing method identify distance as a relevant explanatory variable and offer mixed evidence of a linear relationship between proximity and depreciation (Colwell, 1990; Delaney and Timmons, 1992; Hamilton Schwann, 1995; Boyer et al., 1978).

In Sims and Dent (2005) the negative impacts decrease gradually and disappear for houses situated at 250 meters, whereas living within 100 meters of HVTLs causes a $6 \%-17 \%$ decrease in property value with respect to a property with the same features situated far from the lines. Overall the estimated depreciation varies significantly: it can generally be calculated as between $2 \%$ and 10\% (Hamilton and Schwann, 1995), although it can reach values between 16\% and 29\% for houses near the towers (Boyer et al., 1978; Bond and Hopkins, 2000; Des Rosiers, 2002).

Our study, based on a large sample of directly affected households, tells that the impacts of high voltage power lines are perceived as significant by people living in the affected corridors and do depend on the distance from the infrastructure. Table 5 reports the frequency of respondents reporting no impact versus distance between dwelling and HVTL.

As mentioned above, the implementation of the Euclidean distance offers a first, informative result, but weighting transformations could be considered to test in particular the hypothesis of non-linearity in the impact of distance on WTPs. A non-linear path is at the base, for instance, of the work of Sims and Dent (2005), who suggest that, after a certain distance, the overall perception of the lines vanishes and the infrastructure becomes part of the landscape. We thus tested, as an alternative implementation of the distance variable, a proximity index built as an inverse-squared distance transformation. In that version of the model, WTP values conditional on distance from HVTLs rapidly shrink in the first 50-60 meters from the lines and then asymptotically converge to zero. This non-linear approach, however, does not offer fully satisfactory results in terms of stability and statistical significance of the estimated parameters, and a thorough investigation and comparative analysis of alternative weighting strategies is among our suggestions for future research.

\section{Table 5. Frequency of respondents reporting no impact vs. distance from dwelling (measured by GIS)}

(Approximately here)

Among other infrastructures in the immediacy of the respondents' premises (highways, railways, roads, airports and brownfields), only the proximity of railways and brownfields exhibits a statistically significant negative sign of the parameter. The dummy variables used as indicators of proximity to infrastructures are built on the base of a threshold distance. A sensitivity analysis has been conducted by iteratively re-estimating the model at different distances. The variogram in Figure 3 reports the variations of statistical significance within a range of distances between 200 to 850 meters. Based on this information, we use a threshold distance of 700 meters for railways and of 850 meters for brownfields. 
Figure 3. Variation in the statistical significance of the dummy variables as a function of the distance between the respondents' dwelling and other infrastructures

(Approximately here)

The results confirm that the impact of HVTLs is sensitive to the simultaneous presence of other sources of negative externalities. The average effect of proximity to contaminated sites and railways on the indirect utility function may be interpreted as a substitution effect: environmental externalities with even more serious impacts divert the attention of residents from the HVTLs and reduce the perceived impact of the latter.

\subsection{Aggregate WTP for use in cost-benefit analyses}

A few elements require attention when using the results of stated preference studies, such as this, in cost-benefit analyses informing policy choices. Of particular importance in costbenefit tests of interventions aimed at internalizing externalities imposed by linear infrastructures is the question of the transferability of results obtained from context-specific valuation studies. As a first step in the direction of aiming environmental valuations towards usability in policy decisions we suggest that, instead of providing a standard punctual total WTP obtained in a specific case study, results can be conveyed in a more useful and transferable way by combining information on individual WTPs, the dimension of the considered corridor around the infrastructure, and population density within such corridor.

Through an agent-based simulation we compute values of conditional WTP per household, based on the estimated parameters of the utility function of Model 1 (Table 3), and the values of the covariates observed in the sample, taking into consideration both the GIS and the survey data. The simulated grid has a resolution of $10 \times 10$ meters. Mean and standard deviations of Model 1's covariates (from the descriptive statistics in Table 2) are used to characterize the heterogeneity among cells. The number of individuals per cell is obtained by dispersing our observed household density, according to a national average number of family components of 2.2 (ISTAT, 2013). For the sake of simplicity, we here ignore the presence of regularities and patterns potentially inducing spatial autocorrelation of attributes, such as proximity to other infrastructures, or the fact that families with similar income and education levels may to live closer in space.

Figure 4(a) reports a view of the results of one run (darker values correspond to higher monetary values of the WTPs). Each run of the model samples realizations of the covariates, keeping the relative parameters constant. Figure 4(b) presents the total aggregated WTP. Values in the graph report the average WTP over a sample of 100 runs for each level of population density around the power lines, stacking the contribution from simulated residents at different ranges of distance from the infrastructure. These ranges are then compared with the construction costs of an underground cable with single circuit, with voltage of $400 \mathrm{KV}$, and power rating of $1000 \mathrm{MVA}^{.12}$

In this way, decision makers can identify cost-benefit viability thresholds for undertaking infrastructural projects. In our example, if the corridor within which externalities are perceived is 600 meters wide, a population density of 3000 inhabitants per square kilometre represents the threshold at which the benefits of undergrounding offset the minimum cost.

This exercise offers an approach to generalize the outcomes of previous case-specific cost-benefit studies (such as that by Navrud et al. 2008 for burying transmission lines in Oslo) making the valuation results transferable across local contexts with varying population density and different undergrounding costs.

${ }^{12}$ Cost data have been obtained from the results of the EU project Realisegrid, http://realisegrid.rse-web.it. 
Figure 4. Agent based Simulation (a) of sensitivity of total WTP for cost-benefit analyses of undergrounding projects (b).

\author{
(Approximately here)
}

\title{
5 Conclusions
}

The paper develops an analytical model and a methodological approach for a comprehensive monetary valuation of the externalities imposed by high voltage transmission lines. Our exercise offers decision makers both ready-made estimates conveying indications for location choices and compensation policies, and a replicable example of a methodology for the evaluation of policy alternatives. The outcome could also be employed towards the internalization of externalities from electric power transmission, besides the production externalities usually considered in the literature (e.g. Longo et al., 2008; Realdon, 2013; Sundt and Rehdanz, 2015), in the price of energy commodities. Our results can be summarized as follows.

Pooling together respondents subject to a perception of landscape and environmental impact with respondents perceiving human health risks or with respondents whose real estate property has suffered a severe depreciation produces misleading results: WTPs that differ an order of magnitude would be averaged in a measure that is no longer relevant in terms of operational indications. Our results highlight that a differentiated bid vector, by allowing estimates on homogeneous subsamples, increases the estimation efficiency.

The perceived external costs of infrastructures such as high voltage power lines critically depend, in a nonlinear way, on the distance between residential houses and the infrastructure itself.

The interactions between people and the existing infrastructure on a given territory are defined in a geographical context, so that spatial features (landscape shape and value, prevailing land uses, presence of other infrastructure and so on) are a potentially relevant source of heterogeneity in public preferences. This is particularly significant when linear infrastructures run across wide areas and different environmental systems. Most of these aspects are typically not addressed in existing approaches for the estimation of the social costs of infrastructures, causing them to yield biased estimates. Our methodological choice, merging contingent valuation with a GIS analysis, shows that geo-referenced CV surveys provide a more comprehensive valuation of the various forms of external costs involved. A geographically stratified approach to environmental valuation also draws attention to the general problem of choosing the "right" scale for statistical inference and of the correspondence between the spatial viewpoint of the valuation exercise and the scale of the policies that will be informed by its results. If WTP estimates are required, say, to internalize the social cost of HVTL in a cost-benefit analysis, the valuation study should be designed at same scale as actual decisions - typically regional.

The analysis developed in this paper allows valuation studies to offer a more useful support for decision-makers facing questions relative to planning the construction or undergrounding of infrastructure networks, as well as for negotiating compensative measures. As to location decisions, we provide a synthetic and, at once, more general approach for measuring aggregate WTPs usable in cost-benefit tests taking into account context-specific variables such as the concerned area's population density. As to the negotiation of compensations, an approach delivering more accurate measures of WTPs by accounting for socio-demographic and context variables may represent an instrument for 
more articulate procedures of conflict management. This may prove particularly valuable when the construction of new facilities encounters opposition by the population.

Finally, taking this point of view also re-opens room for studying the econometric models for analysing contingent valuation data best suited to address the problem of the distribution of environmental impacts in a geographical framework.

Acknowledgements. This paper draws from results of a research project funded by the Directorate of Environment of the Piedmont Region and the Office for the Evaluation of Public Investments of the Piedmont Region (NUVAL). We are grateful to Ugo Colombino, Edward Morey, Anna Alberini and Riccardo Scarpa for suggestions on the design of the experiment and methodological insights.

\section{References}

AJZEN I., BROWN T.C., ROSENTHAL L. H., 1996. Information Bias in Contingent Valuation: Effects of Personal Relevance, Quality of Information, and Motivational Orientation. Journal of Environmental Economics and Management 30(1); 43-57.

ANSELIN L., 2003. Spatial Externalities, Spatial Multipliers, and Spatial Econometrics. International Regional Science Review 26(2); 153-166.

ARROW K., SOLOW R., PORTNEY P. R., LEAMER E., RADNER R., SCHUMAN H., 1993. Report of the NOAA Panel on Contingent Valuation. Federal Register 58(10); 4601-4614.

ATKINSON G., DAY B., MOURATO S., PALMER C., 2004. 'Amenity' or 'eyesore'? Negative willingness to pay for options to replace electricity transmission towers. Applied Economics Letters 11; 203-208.

BATEMAN I.J., JONES A.P., LOVETT A.A., LAKE I.R., DAY B.H., 2002. Applying Geographical Information Systems (GIS) to Environmental and Resource Economics. Environmental and Resource Economics 22; 219-269.

BATEMAN I.J., LANGFORD I.H., 1997. Budget-constraint, temporal, and question-ordering effects in contingent valuation studies. Environment and Planning A 29(7); 1215-1228.

BAVAUD F., 1998. Models for spatial weights: a systematic look. Geographical Analysis 30; 153171.

BISHOP R. C., HEBERLEIN T.A., 1979. Measuring Values of Extra-Market Goods: Are Indirect Measures Biased? American Journal of Agricultural Economics 61; 926-30.

BOCKSTAEL N.E., 1996. Modeling economics and ecology: the importance of a spatial perspective. American Journal of Agricultural Economics 78; 1168-1180.

BOND S., HOPKINS J., 2000. The Impact of Transmission Lines on Residential Property Values: Results of a Case Study in a suburb of Wellington. New Zealand Pacific Rim Property Journal 6(2); 52-60.

BORCHERS A.M., DUKE J.M., PARSONS G.R., 2007. Does willingness to pay for green energy differ by source?. Energy Policy 35(6); 3327-3334.

BORD R.J., O'CONNOR R.E., 1997. The gender gap in environmental attitudes: the case of perceived vulnerability to risk. Social Science Quarterly 78(4); 830-840.

BOYER J.C., MITCHELL B., FENTON S., 1978. The socio-economic impacts of electric transmission corridors: a comparative analysis. Department of Man-Environment Studies, University of Waterloo: Ontario.

CHEN W.Y., AERTSENS J., LIEKENS I., BROEKX S., DE NOCKER L., 2014. Impact of perceived importance of ecosystem services and stated financial constraints on willingness to pay for riparian meadow restoration in Flanders (Belgium). Environmental Management 54(2); 346-59.

CLEMENTI A., 1996. La ricerca ITATEN: forme del territorio italiano. Urbanistica 106; 6-61. 
COLWELL P.F., FOLEY K.W., 1979. Electric transmission lines and the selling price of residential property. The Appraisal Journal, October; 490-499.

COLWELL P.F., 1990. Power Lines and Land Value. Journal of Real Estate Research 5(1); 117-127.

COTTON M., DEVINE-WRIGHT P., 2013. Putting pylons into place: a UK case study of public perspectives on the impacts of high voltage overhead transmission lines. Journal of Environmental Planning and Management 56(8); 1225-1245.

CSERGE, IOS-NLH, IVM, CAS, DAE-UoV, 1999. Benefits Transfer and the Economic Valuation of Environmental Damage in the European Union: With Special Reference to Health. Report to Directorate General of Environment, European Commission: Brussels.

DELANEY C.J., TIMMONS D., 1992. High voltage power lines: do they affect residential property values? Journal of Real Estate Research 7(3); 315-329.

DES ROSIERS F., 2002. Power Lines, Visual Encumbrance and House Values: A Microspatial Approach to Impact Measurement. Journal of Real Estate Research 23(3); 275-301.

DUPONT D.P., 2004. Do children matter? An examination of gender differences in environmental valuation. Ecological Economics 3(1); 273-286.

ECORYS, 2010. Study on Employment, Growth and Innovation in Rural Areas (SEGIRA). Main Repor. Rotterdam (The Netherlands). Available at: http://ec.europa.eu/agriculture/analysis/external/employment/full-text_en.pdf

EK K., 2005. Public and private attitudes towards "green" electricity: the case of Swedish wind power. Energy Policy 33(13); 1677-1689.

EUROPEAN COMMISSION, 1995. ExternE: Externalities of Energy. Volumes 1-10. Directorate General for Research, Sustainable Energy Systems, Brussels.

GENELETTI D., 2002. Ecological evaluation for environmental impact assessment. PHD Thesis Netherlands Geographical Studies: Utrecht.

GALLIMORE P., JAYNE M.R., 1999. Public and professional perceptions of HVOTL risks: the problem of circularity. Journal of Property Research 16(3); 243-55.

GIACCARIA S., FRONTUTO V., 2012. Perceived health status and environmental quality in the assessment of external costs of waste disposal facilities. An empirical investigation. Waste Management and Research 30(8); 864-70.

HAIDER M., HAROUN A., MILLER E.J., 2001. The Impact of Power Lines on Freehold Residential Property Values in the Greater Toronto Area. Canadian Regional Science Meetings 200: Montreal.

HAMILTON S.W., SCHWANN G.M., 1995. Do High Voltage Electric Transmission Lines Affect Property Values?. Land Economics 81(4); 436-444.

HANEMANN W.M., 1984. Welfare Evaluation in Contingent Valuation Experiments with Discrete Responses. American Journal of Agricultural Economics 66(3); 332-41.

HOEHN J. P., RANDALL A., 2002. The effects of resource quality information on resource injury perceptions and contingent values. Resource and Energy Economics 24(1-2); 13-31.

ISTAT, 2013. XV Censimento della popolazione e delle abitazioni 2011. Roma. http://www.istat.it/en/files/2013/12/Nota-diffusione_popolazione_e_famiglie20122013.pdf

JOHNSTON R.J., SWALLOW S.K., BAUER D.M., 2002. Spatial factors and Stated Preferences Values for Public Goods: Considerations for Rural Land Use. Land Economics 74(4); 481-500.

JU H.-C., YOO S.-H., 2014. The environmental cost of overhead power transmission lines: the case of Korea, Journal of Environmental Planning and Management 57(6); 812-828.

KINNARD W.N., 1967. Tower Lines and Residential Property Values. The Appraisal Journal, April, 269-84.

KREWITT W., TRUKENMUELLER A., MAYERHOFER P. and FREIDRICH R., 1995. EcoSense - an integrated tool for environmental impact analysis. In: Kremers, $\mathrm{H}$ and Pillmann, W, Editors, 1995. Space and time in environmental information systems. Umwelt-Inf Aktuell Band 7, Metropolis-Verlag, Marburg (Germany).

KROLL C., PRIESTLEY T., 1992. The effects of overhead transmission lines on property values: a review and analysis of literature. Siting and Environmental Planning Task Force, Edison Electrical Institute: Piedmont, Canada.

KUNG H., SEAGLE C.F., 1992. Impact of Power Transmission Lines on Property Values: A Case Study. The Appraisal Journal 60(3); 413-418.

LONGO A., HOYOS D., MARKANDYA A., 2012. Willingness to pay for ancillary benefits of climate change mitigation. Environmental and Resource Economics 51(1);119-140. 
LONGO A., MARKANDYA A., PETRUCCI M., 2008. The internalization of externalities in the production of electricity: willingness to pay for the attributes of a policy for renewable energy. Ecological Economics 67(1); 140-152.

LONGO A., HOYOS D., MARKANDYA A., 2015. Sequence Effects in the Valuation of Multiple Environmental Programs Using the Contingent Valuation Method. Land Economics 91(1); 2035.

MAY D.E., CORBIN A.R., HOLLINS P.D., 2011. Identifying Determinants of Residential Property Values in South London. Review of Economic Perspectives 11(1); 3-11.

McNAIR B.J., ABELSON P., 2010. Estimating the Value of Undergrounding Electricity and Telecommunications Networks, The Australian Economic Review 43(4); 376-388.

McNAIR B.J., BENNETT J., HENSHER D.A., ROSE J.M., 2011a. Households' willingness to pay for overhead-to-underground conversion of electricity distribution networks, Energy Policy, vol. 39(5): 2560-2567.

McNAIR B.J., BENNETT J., HENSHER D.A., 2011b. A comparison of responses to single and repeated discrete choice questions, Resource and Energy Economics 33(3); 554-571.

MEDRANO F.A., CHURCH R.L., 2014. Corridor Location for Infrastructure Development: A Fast Bi-objective Shortest Path Method for Approximating the Pareto Frontier. International Regional Science Review 37(2); 129-148.

MITCHELL R., CARSON R.T., 1989. Using Surveys to Value Public Goods: The Contingent Valuation Method. Washington, DC: Resources For the Future.

NAVRUD S., READY R.C., MAGNUSSEN K., BERGLAND O., 2008. Valuing the social benefits of avoiding landscape degradation from overhead power transmission lines: Do underground cables pass the benefit-cost test?, Landscape Research 33(3): 281-296.

PEARCE D.W., 2001. Energy Policy and Externalities: an Overview. Paper prepared for OECD Nuclear Energy Agency, Keynote address to Workshop on Energy Policy and Externalities: the Life Cycle Analysis Approach. Paris; November; 15-16.

REALDON M., 2013. Revisiting the pricing of commodity futures and forwards. Applied Financial Economics 23(3); 233-240.

ROSATO P., CANDIDO A., GALVAN A., MARTIN C., 2004. La valutazione dei costi e dei benefici dell'interramento delle linee elettriche: un caso di studio nella bassa pianura veneta. Genio Rurale 6;11-20.

SARDIANOU P., GENOUDI P., 2013. Which factors affect the willingness of consumers to adopt renewable energies?. Renewable Energy 57; 1-4.

SCARPA R., WILLIS K., 2010. Willingness-to-pay for renewable energy: Primary and discretionary choice of British households' for micro-generation technologies. Energy Economics 32(1); 129136.

SIMS S., DENT P., 2005. High-voltage Overhead Power Lines and Property Values: A Residential Study in the UK. Urban Studies 42(4); 665-694.

SOINI K., POUTA E., SALMIOVIRTA M., UUSITALO M., KIVINEN T., 2011. Local residents' perceptions of energy landscape: the case of transmission lines. Land Use Policy 28(1); 294-305.

STERN P., DIETZ T., KALOF L., 1993. Value orientations, gender, and environmental concern. Environment and Behaviour 25(3); 322-348.

STEVENS, T.H., DECOTEAU N.E., WILLIS C.E., 1997. Sensitivity of Contingent Valuation to Alternative Payment Schedules. Land Economics 73(1); 140-148.

STRAZZERA E., SCARPA R., CALIA P., GARROD G.D., WILLIS K.G., 2003. Modelling zero values and protest responses in contingent valuation surveys. Applied economics 35(2); 133-138.

STUMBORG B.E., BAERENKLAU K.A., BISHOP R.C., 2001. Nonpoint Source Pollution and Present Values: A Contingent Valuation Study of Lake Mendota. Review of Agricultural Economics 23(1); 120-132.

SUMPER A., BOIX-ARAGONÈS O., VILLAFÁFILA-ROBLES R., BERGAS-JANÉ J., RAMÍREZ-PISCO R., 2010. Methodology for the assessment of the impact of existing high voltage lines in urban areas, Energy Policy 38(10); 6036-6044.

SUNDT S., REHDANZ K., 2015. Consumers' willingness to pay for green electricity: A metaanalysis of the literature, Energy Economics 51; 1-8.

TEMPESTA T., MARAZZI M., 2005. Disponibilità a pagare e disponibilità ad accettare per la riduzione dell'impatto paesaggistico delle linee elettriche dell'alta tensione. Aestimum 46; 65-95. 
TELSER H., ZWEIFEL P., 2007. Validity of discrete-choice experiments evidence for health risk reduction. Applied Economics 39(1); 69-78.

TKAC J., 1998. The effects of information on willingness to pay values of endangered species. American Journal of Agricultural Economics 80;1214-1220.

WHITEHEAD J.C., BLOMQUIST G.C., 2009. The use of contingent valuation in benefit-cost analysis. in Anna Alberini, James R. Kahn (eds), Handbook on Contingent Valuation, Edward Elgar, Cheltenham, UK.

XIE F., PULLENAYEGUM E., GAEBEL K., OPPE M., KRABBE P., 2014. Eliciting Preferences to the EQ-5D-5L Health States: Discrete Choice Experiment or Multiprofile Case of BestWorst Scaling?. European Journal Of Health Economics 15(3); 281-288. 
Table 1. Existing monetary valuations of HVTL externalities

\begin{tabular}{|c|c|c|c|}
\hline Author & Technique & Corridor width & Results \\
\hline Kinnard (1967) & $\begin{array}{l}\text { Interviews to } \\
\text { owners }\end{array}$ & $\begin{array}{l}\text { Four categories. The } \\
\text { farthest houses are at } \\
61 \mathrm{~m} \text { ( } 200 \text { feet })\end{array}$ & Low reduction in real estate values (approximately $3 \%$ ) \\
\hline $\begin{array}{l}\text { Clarke and } \\
\text { Treadway (1972) }\end{array}$ & $\begin{array}{l}\text { Hedonic } \\
\text { price }\end{array}$ & - & $\begin{array}{l}\text { Significant reduction for residential houses but not for commercial } \\
\text { activities }\end{array}$ \\
\hline $\begin{array}{l}\text { Boyer et al. } \\
(1978)\end{array}$ & $\begin{array}{l}\text { Interviews to } \\
\text { owners }\end{array}$ & 1 mile & $\begin{array}{l}\text { Real estate value reduction approximately } 16 \% \text { and } 29 \% \text { depending on } \\
\text { the distance from the HVTL }\end{array}$ \\
\hline $\begin{array}{l}\text { Colwell and } \\
\text { Foley (1979) }\end{array}$ & $\begin{array}{l}\text { Hedonic } \\
\text { price }\end{array}$ & $122 \mathrm{~m}$ (400 feet) & $\begin{array}{l}\text { No effects for houses within } 60 \mathrm{~m} \text {, reduction only for houses within } 15 \\
\mathrm{~m} \text {. }\end{array}$ \\
\hline Colwell (1990) & $\begin{array}{l}\text { Hedonic } \\
\text { price }\end{array}$ & $122 \mathrm{~m}$ (400 feet) & $\begin{array}{l}\text { Reduction in real estate values related to the proximity of houses to the } \\
\text { HVTLs }\end{array}$ \\
\hline $\begin{array}{l}\text { Kung and Seagle } \\
(1992)\end{array}$ & $\begin{array}{l}\text { Hedonic } \\
\text { price }\end{array}$ & & $\begin{array}{l}\text { No effect with statistical support, approximately } 72 \% \text { of the owners } \\
\text { declare the HVTL has no influence on real estate values }\end{array}$ \\
\hline $\begin{array}{l}\text { Delaney and } \\
\text { Timmons (1992) }\end{array}$ & $\begin{array}{l}\text { Hedonic } \\
\text { price }\end{array}$ & - & $\begin{array}{l}\text { Reduction of real estate values up to } 10 \% \text { depending on the distance } \\
\text { from the HVTL }\end{array}$ \\
\hline $\begin{array}{l}\text { Hamilton and } \\
\text { Schwann (1995) }\end{array}$ & $\begin{array}{l}\text { Hedonic } \\
\text { price }\end{array}$ & $200 \mathrm{~m}$ & $\begin{array}{l}\text { Reduction between } 1.1 \% \text { for houses at } 200 \text { meters from the lines and } \\
6.3 \% \text { for those at } 100 \text { meters }\end{array}$ \\
\hline $\begin{array}{l}\text { Callanan and } \\
\text { Hargreaves } \\
(1995)\end{array}$ & $\begin{array}{l}\text { Hedonic } \\
\text { price }\end{array}$ & $300 \mathrm{~m}$ & $\begin{array}{l}\text { In proximity of a tower ( } \leq 10 \text { meters) the reduction can reach } 27.3 \% \text { of } \\
\text { the real estate value. }\end{array}$ \\
\hline $\begin{array}{l}\text { Bond and } \\
\text { Hopkins (2000) }\end{array}$ & $\begin{array}{l}\text { Hedonic } \\
\text { price }\end{array}$ & $400 \mathrm{~m}$ & Effects on the real estate values are not statistically significant \\
\hline $\begin{array}{l}\text { Des Rosiers } \\
(2002)\end{array}$ & $\begin{array}{l}\text { Hedonic } \\
\text { price }\end{array}$ & $488 \mathrm{~m}$ & Reduction up to $20 \%$ for houses very close to HVTLs \\
\hline $\begin{array}{l}\text { Haider et al. } \\
\text { (2001) }\end{array}$ & $\begin{array}{l}\text { Hedonic } \\
\text { price }\end{array}$ & $3000 \mathrm{~m}$ & $\begin{array}{l}\text { Average reduction of } 4-6.2 \% \text { for properties within } 1 \mathrm{~km} \text { from HVTLs. } \\
\text { Little evidence of impact on property values at distance }>500 \mathrm{~m} \text {. }\end{array}$ \\
\hline $\begin{array}{l}\text { Rosato et al. } \\
\text { (2004) }\end{array}$ & $\begin{array}{l}\text { Contingent } \\
\text { Valuation }\end{array}$ & $1500 \mathrm{~m}$ & $\begin{array}{l}\text { Average WTP approximately } € 530 \text { per household. No statistical } \\
\text { relation between distance and WTP. }\end{array}$ \\
\hline $\begin{array}{l}\text { Atkinson et al. } \\
\text { (2004) }\end{array}$ & $\begin{array}{l}\text { Choice } \\
\text { Experiments }\end{array}$ & $500 \mathrm{~m}-5 \mathrm{~km}$ & $\begin{array}{l}\text { Household WTPs for } 5 \text { different HVTL tower designs estimated } \\
\text { between } 1.85 £ \text { and } 2.03 £ \text {. }\end{array}$ \\
\hline $\begin{array}{l}\text { Tempesta and } \\
\text { Marazzi (2005) }\end{array}$ & $\begin{array}{l}\text { Contingent } \\
\text { Valuation }\end{array}$ & - & $\begin{array}{l}\text { Median WTA approximately } € 200 \text {, median WTP approximately } € 80 \\
\text { per person. Does not investigate the relationship between WTP/WTA } \\
\text { and proximity to the HVTLs. }\end{array}$ \\
\hline $\begin{array}{l}\text { Navrud et al. } \\
(2008)\end{array}$ & $\begin{array}{l}\text { Contingent } \\
\text { Valuation }\end{array}$ & $\begin{array}{l}\text { Three zones }(0-200 \mathrm{~m} \\
200-1000 \mathrm{~m} ;>1000 \mathrm{~m})\end{array}$ & $\begin{array}{l}\text { Mean WTP decreases with distance from HVTL. Households' yearly } \\
\text { WTP is estimated to be } 1141 \text { NOK for houses within } 200 \text { meters from } \\
\text { the HVTL }\end{array}$ \\
\hline $\begin{array}{l}\text { McNair and } \\
\text { Abelson }(2010)\end{array}$ & $\begin{array}{l}\text { Hedonic } \\
\text { price }\end{array}$ & - & $\begin{array}{l}\text { Undergrounding low-voltage electricity and telecommunication } \\
\text { networks increase house prices by } 2.9 \%\end{array}$ \\
\hline May et al. (2011) & $\begin{array}{l}\text { Hedonic } \\
\text { price }\end{array}$ & - & $\begin{array}{l}\text { Real estate values increase by } 0.03 \% \text { when the distance to the HVLT } \\
\text { increases by } 1 \% \text {. }\end{array}$ \\
\hline $\begin{array}{l}\text { McNair et al. } \\
(2011 a, b)\end{array}$ & $\begin{array}{l}\text { Choice } \\
\text { Experiment }\end{array}$ & - & $\begin{array}{l}\text { Average WTP is at least A } \$ 6838 \text { per household and it increases for } \\
\text { families with higher income. }\end{array}$ \\
\hline $\begin{array}{l}\text { Ju and Yoo } \\
(2014)\end{array}$ & $\begin{array}{l}\text { Choice } \\
\text { Experiment }\end{array}$ & - & $\begin{array}{l}\text { Households' monthly WTP to reduce the visual disamenity caused by } 1 \\
\mathrm{~km} \text { of HVTL, expressed as higher electricity charges, is US } \$ 0.22 \text {. }\end{array}$ \\
\hline
\end{tabular}


Table 2. Descriptive statistics

\begin{tabular}{|c|c|c|c|c|}
\hline Variable name & Mean & St./Dev. & Variable Description & Type \\
\hline Biodiversity & $6.0 \%$ & - & $\begin{array}{l}\text { Dummy identifying respondents who rank } \\
\text { ecological and biodiversity impacts as the most } \\
\text { relevant damage from HVTLs }\end{array}$ & Dummy \\
\hline Health & $52.6 \%$ & - & $\begin{array}{l}\text { Dummy identifying respondents who rank health } \\
\text { impacts as the most relevant damage from HVTLs }\end{array}$ & Dummy \\
\hline Landscape & $22.3 \%$ & - & $\begin{array}{l}\text { Dummy identifying respondents who rank } \\
\text { landscape and visual encumbrance as the most } \\
\text { relevant damage from HVTLs. }\end{array}$ & Dummy \\
\hline Income: & $€ 22,799.91$ & $€ 17,441$ & Yearly income & Count \\
\hline Children & $28.5 \%$ & - & Presence of children (younger than 14) & Dummy \\
\hline Age & 52.8 & 15.864 & Age & Count \\
\hline Gender: & & - & & \\
\hline Women & $64.1 \%$ & - & Female & Dummy \\
\hline Men & $35.9 \%$ & - & & \\
\hline Family size & 2,936 & 1.119 & Number of household components & Count \\
\hline Education & 9.87 & 4.305 & Number of years of education & Count \\
\hline HVTL distance & 324.57 & 220.241 & Euclidean distance to the infrastructure (meters) & Cardinal \\
\hline Amenities & 0.335 & 0.735 & $\begin{array}{l}\text { Number of environmental and built heritage goods } \\
\text { in non-urban environment }\end{array}$ & Count \\
\hline Highway & 0.078 & 0.268 & $\begin{array}{l}\text { Presence of a highway route (within } 600 \text { meters of } \\
\text { the respondent's home) }\end{array}$ & Dummy \\
\hline Railway & 0.151 & 0.358 & $\begin{array}{l}\text { Presence of a railway route (within } 400 \text { meters of } \\
\text { the respondent's home) }\end{array}$ & Dummy \\
\hline $\begin{array}{l}\text { Contaminated } \\
\text { sites }\end{array}$ & 0.061 & 0.159 & $\begin{array}{l}\text { Presence of a highly polluted site (within } 1000 \\
\text { meters of the respondent's home) }\end{array}$ & Dummy \\
\hline Protected areas & 0.7375 & 0.440 & $\begin{array}{l}\text { Presence of environmental ties within the } \\
\text { municipality (NUTS4 unit) }\end{array}$ & Dummy \\
\hline
\end{tabular}


Table 3. Full and reduced models for pooled analysis

\begin{tabular}{|c|c|c|c|}
\hline Log-likelihood & $\begin{array}{l}\text { Model 1 } \\
-861.503 \\
\end{array}$ & $\begin{array}{l}\text { Model 2 } \\
-\mathbf{8 8 7 . 2 3 8 4} \\
\end{array}$ & $\begin{array}{l}\text { Model 3 } \\
-918.76 \\
\end{array}$ \\
\hline Variable & $\begin{array}{l}\text { Coefficient } \\
\text { [b/St.Err.] }\end{array}$ & $\begin{array}{l}\text { Coefficient } \\
\text { [b/St.Err.] }\end{array}$ & $\begin{array}{l}\text { Coefficient } \\
\text { [b/St.Err.] }\end{array}$ \\
\hline Bid & $\begin{array}{l}-0.0034477 \\
{[-9.399]^{* * *}}\end{array}$ & $\begin{array}{l}-0.00396 \\
{[-11.220] * * *}\end{array}$ & $\begin{array}{l}-0.00284 \\
{[-9.701]^{* * *}}\end{array}$ \\
\hline$d_{2} B i d$ & $\begin{array}{l}0.00230394 \\
{[5.112]^{* * *}}\end{array}$ & $\begin{array}{l}0.002655 \\
{[6.103]^{* * *}}\end{array}$ & $\begin{array}{l}0.00207 \\
{[4.987]^{* * *}}\end{array}$ \\
\hline$d_{3} B i d$ & $\begin{array}{l}0.00330952 \\
{[9.132]^{* * *}}\end{array}$ & $\begin{array}{l}0.003822 \\
{[10.973]^{* * *}}\end{array}$ & $\begin{array}{l}0.002734 \\
{[9.416]^{* * *}}\end{array}$ \\
\hline Health & $\begin{array}{l}0.55345457 \\
{[2.724]^{* * *}}\end{array}$ & $\begin{array}{l}0.366615 \\
{[1.848]^{* *}}\end{array}$ & $\begin{array}{l}0.898596 \\
{[5.112]^{* * *}}\end{array}$ \\
\hline Biodiversity & $\begin{array}{l}0.50694471 \\
{[3.649]^{* * *}}\end{array}$ & $\begin{array}{l}0.305784 \\
{[2.308]^{* *}}\end{array}$ & $\begin{array}{l}0.73623 \\
{[6.676]^{* * *}}\end{array}$ \\
\hline Landscape & $\begin{array}{l}0.41795477 \\
{[2.561]^{* *}}\end{array}$ & $\begin{array}{l}0.220045 \\
{[1.395]}\end{array}$ & $\begin{array}{l}0.676033 \\
{[4.948]^{* * *}}\end{array}$ \\
\hline Children & $\begin{array}{l}0.281648 \\
{[2.257]^{* *}}\end{array}$ & $\begin{array}{l}0.244988 \\
{[2.004]^{* *}}\end{array}$ & - \\
\hline Education & $\begin{array}{l}0.06252925 \\
{[4.34]^{* * *}}\end{array}$ & $\begin{array}{l}0.024278 \\
{[1.876]^{* *}}\end{array}$ & - \\
\hline Income & $\begin{array}{l}.213405 \mathrm{D}-04 \\
{[4.348]^{* * *}}\end{array}$ & $\begin{array}{l}.164591 \mathrm{D}-04 \\
{[3.471]^{* * *}}\end{array}$ & - \\
\hline Female & $\begin{array}{l}0.00207746 \\
{[2.757]^{* * *}}\end{array}$ & $\begin{array}{l}0.002254 \\
{[2.999]^{* * *}}\end{array}$ & - \\
\hline Distance HVTL & $\begin{array}{l}-0.00139934 \\
{[-5.396]^{* * *}}\end{array}$ & - & - \\
\hline Amenities & $\begin{array}{l}0.00088381 \\
{[1.794]^{*}}\end{array}$ & - & - \\
\hline Highway & $\begin{array}{l}-0.25847201 \\
{[-1.163]}\end{array}$ & - & - \\
\hline Railway & $\begin{array}{l}-0.44311078 \\
{[-2.701]^{* * *}}\end{array}$ & - & - \\
\hline Contaminated sites & $\begin{array}{l}-0.26220076 \\
{[-2.242]^{* *}}\end{array}$ & - & - \\
\hline Protected areas & $\begin{array}{l}0.22660738 \\
{[1.876]^{*}}\end{array}$ & - & - \\
\hline \multicolumn{4}{|l|}{ LR Test } \\
\hline Model 2 vs. Model 1 & & Rejected $\mathrm{H}_{\mathrm{o}}$ & \\
\hline Model 2 vs. Model 3 & & & Rejected $\mathrm{H}_{\mathrm{o}}$ \\
\hline Number of observations & 1223 & 1223 & 1223 \\
\hline
\end{tabular}

$*, * *, * *$ Coefficients different from zero with an error probability of $10 \%, 5 \%, .1 \%$ 
1

2

3

4

5

6

7

8

9

10

11

12

13

14

15

16

17

18

19

20

21

22

23

24

25

26

27

28

29

30

31

32

33

34

35

36

37

38

39

40

41

42

43

44

45

46

47

48

49

50

51

52

53

54

55

56

57

58

59

60

Table 4. Estimation on subsamples. Unconditional WTP and confidence intervals

\begin{tabular}{|c|c|c|c|c|c|}
\hline & Coefficient & $\begin{array}{l}\text { Standard } \\
\text { Error }\end{array}$ & Asy-t. & $\mathbf{P}[|\mathbf{Z}|>\mathbf{Z}]$ & $\begin{array}{l}\text { E(WTP) } \\
\text { (Dev. St.) }\end{array}$ \\
\hline \multicolumn{6}{|c|}{ Subsample vector 1} \\
\hline Constant & 1.026 & 0.075 & 13.644 & 0.000 & $€ 189^{13}$ \\
\hline Bid & -0.005 & 0.000 & -21.556 & 0.000 & $(€ 11)$ \\
\hline
\end{tabular}

Subsample vector 2

$\begin{array}{llllll}\text { Constant } & 1.997 & 0.287 & 6.943 & 0.000 & \mathbf{€ 5 6 9} \\ \text { Bid } & -0.003 & 0.000 & -8.048 & 0.000 & (€ 57)\end{array}$

Subsample vector 3

\begin{tabular}{llllll}
\multicolumn{6}{l}{ Subsample vector $\mathbf{3}$} \\
\hline Constant & 0.849 & 0.238 & 3.564 & 0.000 & $\mathbf{€ 3 . 7 5 3}$ \\
Bid & -0.000 & $0.403 \mathrm{D}-04$ & -5.604 & 0.000 & $(€ 995)$ \\
\hline
\end{tabular}

13 The WTPs are per household. 
Table 5. Frequency of respondents reporting no impact vs. distance from dwelling (measured by GIS)

\begin{tabular}{ll} 
Distance & Frequency \\
\hline $0-50$ meters & $15(6.9 \%)$ \\
$50-200$ meters & $69(31.8 \%)$ \\
$200-1000$ meters & $132(60.8 \%)$ \\
\hline
\end{tabular}

10

11

12

13

14

15

16

17

18

19

20

21

22

23

24

25

26

27

28

29

30

31

32

33

34

35

36

37

38

39

40

41

42

43

44

45

46

47

48

49

50

51

52

53

54

55

56

57

58

59

60 


\section{List of figures}

Figure 1. Map of sample strata

Figure 2. Price vectors auto-selection criterion

Figure 3. Variation in the statistical significance of the dummy variables as a function of the distance between the respondents' dwelling and other infrastructures

Figure 4. Agent based Simulation (a) of sensitivity of total WTP for cost-benefit analyses of undegrounding projects (b). 
Legend

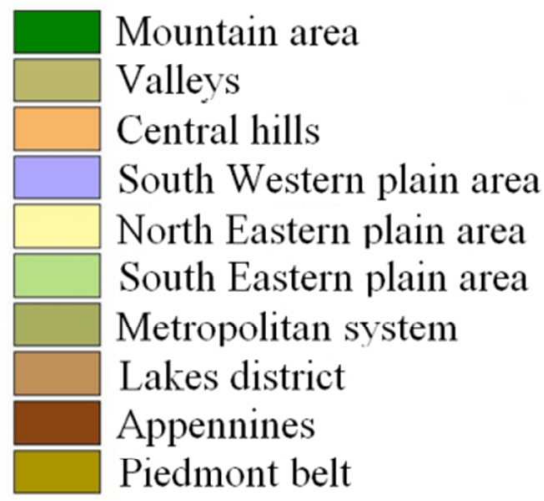

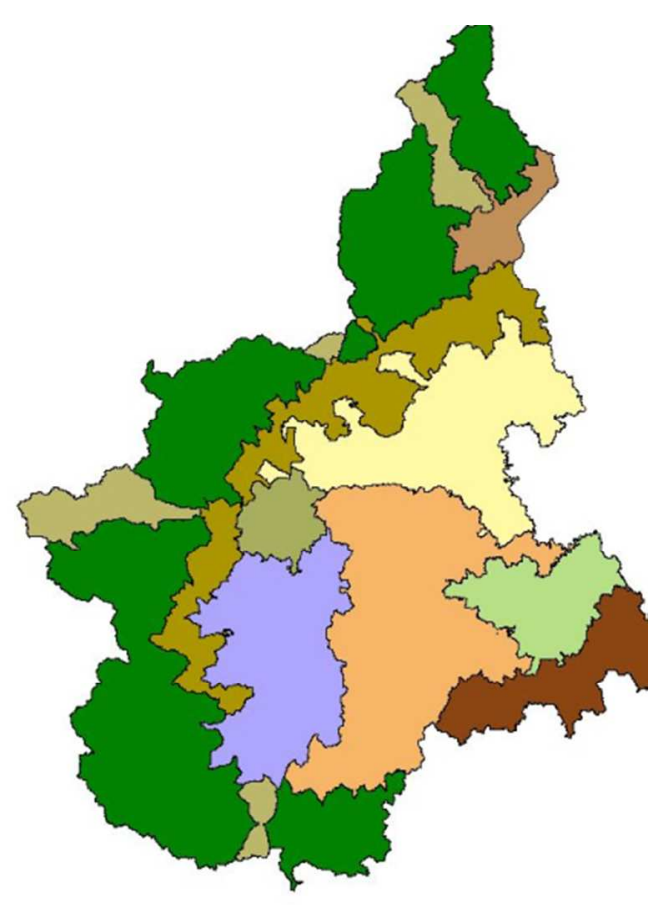

Figure 1. Map of sample strata $98 \times 69 \mathrm{~mm}(220 \times 220$ DPI $)$ 


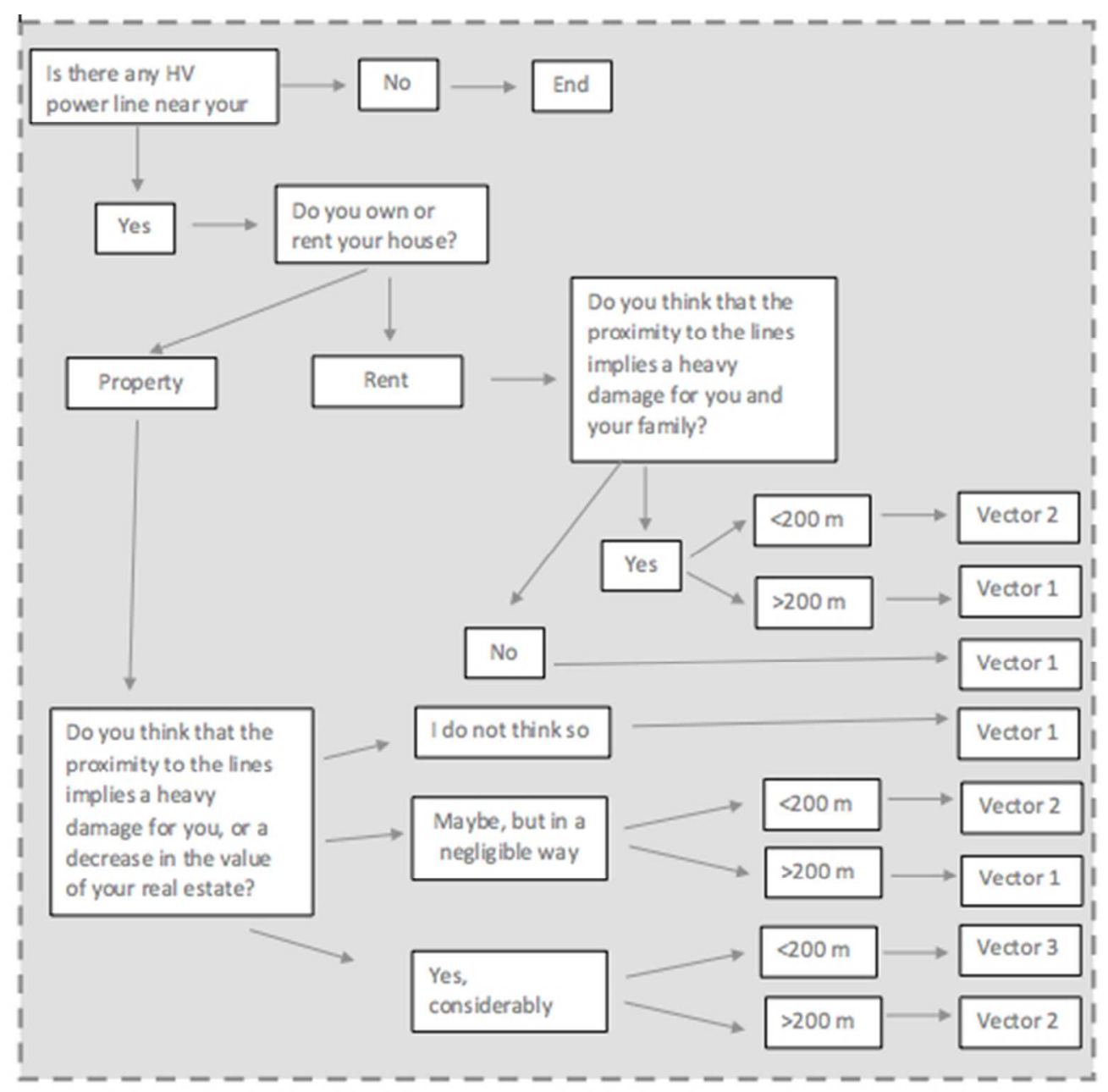

Figure 2. Price vectors auto-selection criterion $178 \times 174 \mathrm{~mm}(72 \times 72 \mathrm{DPI})$ 
Figure 3. Variation in the statistical significance of the dummy variables as a function of the distance between the respondents' dwelling and other infrastructures $151 \times 80 \mathrm{~mm}(150 \times 150$ DPI $)$ 


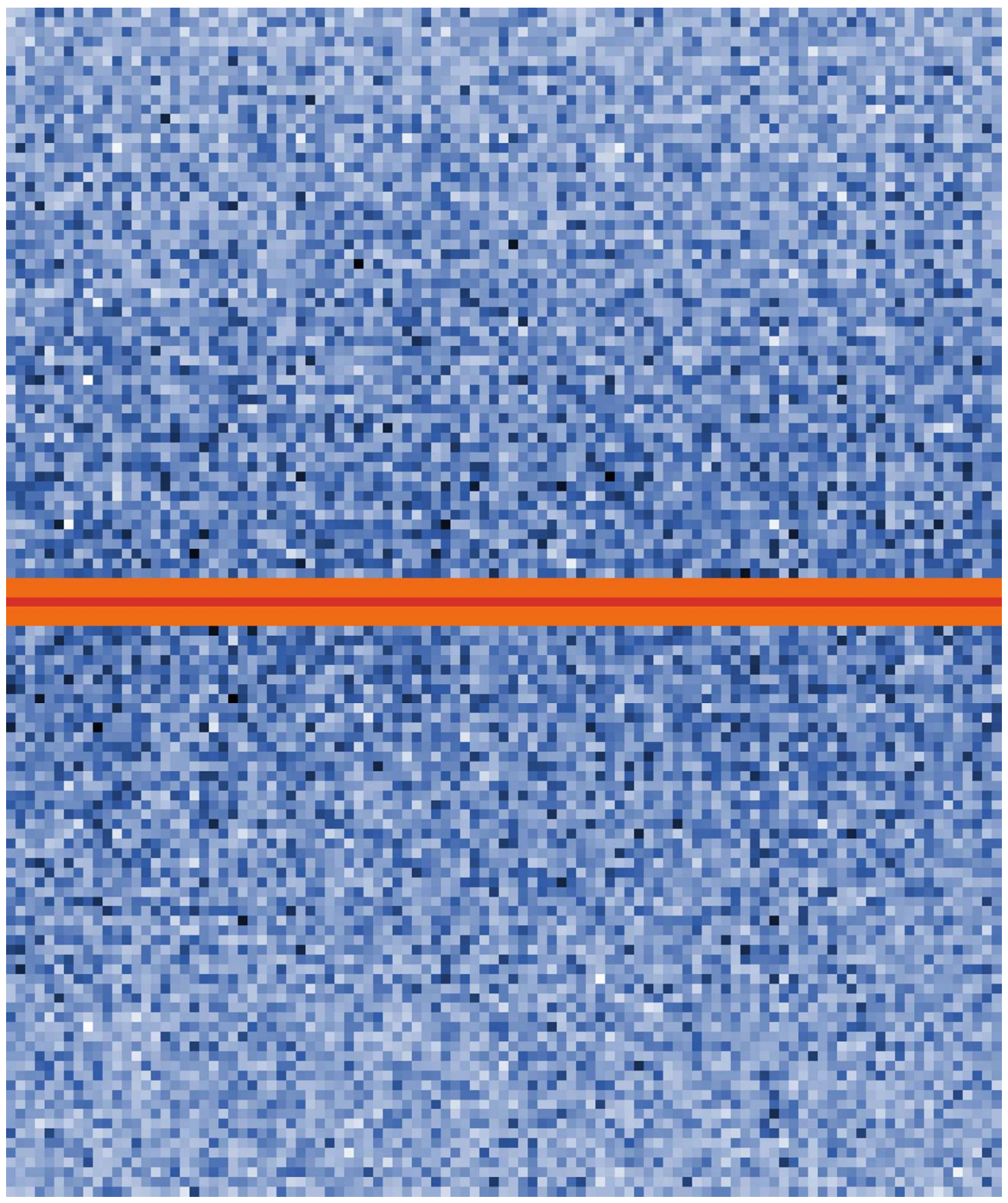

Figure 4. Agent based Simulation (a) of sensitivity of total WTP for cost-benefit analyses of undegrounding projects (b).

$354 \times 423 \mathrm{~mm}(96 \times 96$ DPI $)$ 


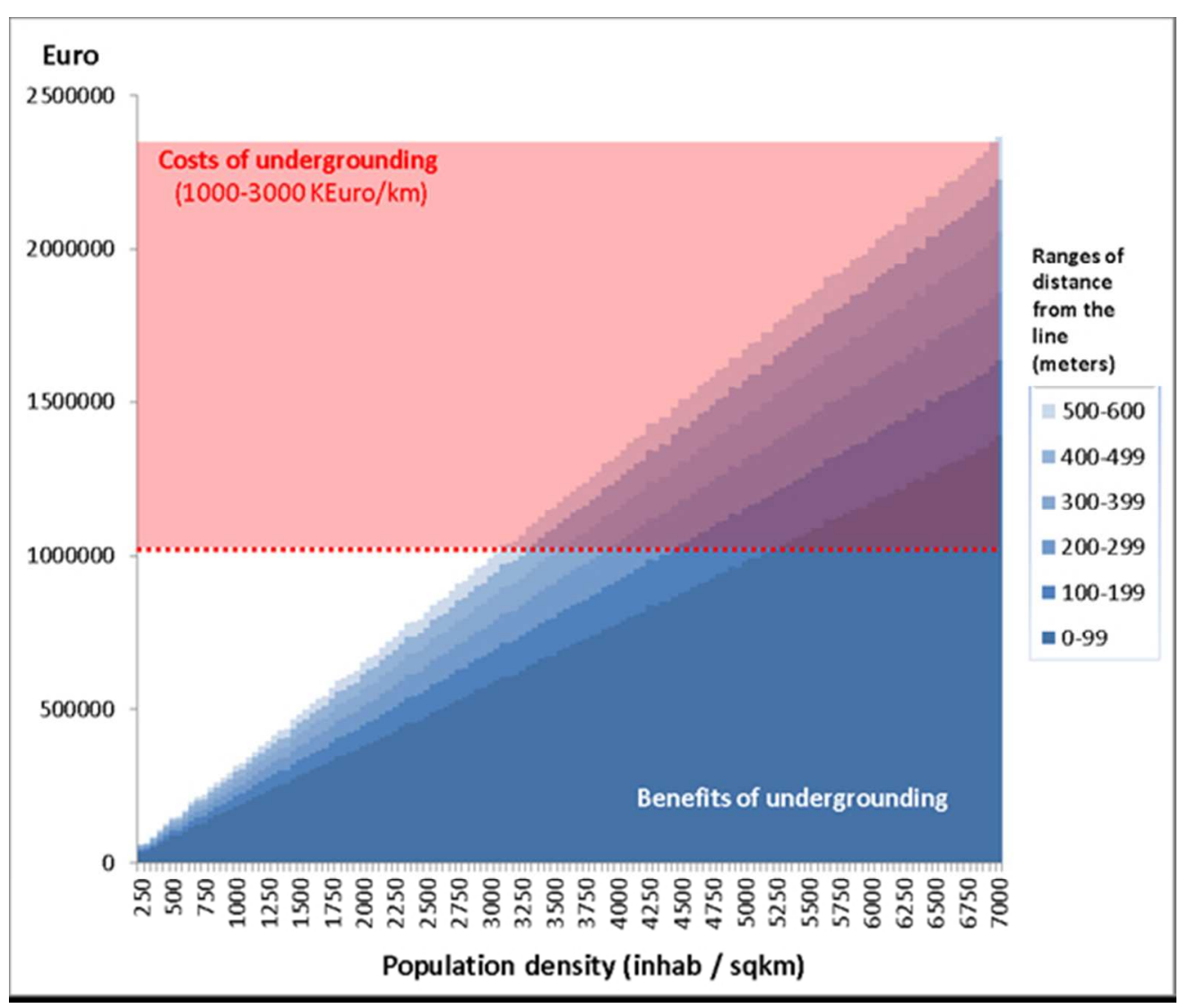

Figure 4. Agent based Simulation (a) of sensitivity of total WTP for cost-benefit analyses of undegrounding projects (b).

$164 \times 138 \mathrm{~mm}(96 \times 96$ DPI) 